\title{
FACTORS INFLUENCING THE INTENSITY OF USING DIGITAL SOCIAL NETWORKS AMONG INDONESIAN MILLENNIAL TOURISTS
}

\author{
Annisa Husnul Latifah \\ Universitas Indonesia \\ Hapsari Setyowardhani* \\ Universitas Indonesia
}

\begin{abstract}
Millennials are typically fond of uploading their travel photos to social media to gain social recognition. Lombok is a tourist destination with considerable potential to increase the value and social status of its visitors, as it offers enough attractions to be considered among the world's favorite celebrity tourist destinations; it is also globally renowned for its diverse natural and cultural beauty. This descriptive quantitative research aims to examine the effect of self-congruity, perceived social value, and experience satisfaction toward the intensity of using a digital social network to reinforce the identity of millennial users in Indonesia. This research involved 214 respondents who visited Lombok for leisure and used a digital social network to inform others of their tourism experience. After being analyzed with structural equation modelling as the data processor, the results show a direct and positive effect between perceived social value and the intensity of using a digital social network but no direct and positive effect between experience self-congruity and experience satisfaction on the intensity of using a digital social network.
\end{abstract}

Keywords: digital social network, perceived social value, satisfaction, self-congruity, tourism

Received: 29 January 2019

Accepted: 12 June 2020

\section{INTRODUCTION}

\subsection{Lombok and Indonesia's Tourist Behaviour}

The tourism industry has had significant influence on improving Indonesia's economy, as evidenced by the country's increased gross domestic product (GDP). In 2015, tourism accounted for $10 \%$ of Indonesia's total GDP and for $4.23 \%$ in 2016 . This number is the highest in Southeast Asia (Kementrian Pariwisata Republik Indonesia, 2016). Furthermore, based on the Deputi Bidang Pengembangan Kelembagaan Kepariwisataan Kementerian Pariwisata, (2017), the number of domestic tourist trips increased by $3.09 \%$ from 2015 to 2016 , outstripping the $2.06 \%$ increase in domestic tourist travel from 2014 to $2015 ; 2018$ saw an increase in the number of domestic tourist

\footnotetext{
* Corresponding Author: Management Department, Faculty of Economics and Business; Address: Widjojo Nitisastro Campus, Jl. Prof. DR. Sumitro Djojohadikusumo, Kukusan, Beji, Depok, West Java, 16424; Phone: +6281310742070; Email: hapsari.setyowardhani@ui.ac.id
} 
trips, rising to $12.37 \%$ from 2017 (303.4 million times in trips), and it accounts for $21 \%$ raising for the last five years. Domestic tourist shopping also rose $12.89 \%$ from 2017 and $63.6 \%$ over the last five years (Katadata, 2019a).

The millennial generation travels more than any other generation (Euromonitor, 2017). Millennials also tend to prefer domestic tourist destinations because they are more affordable in terms of cost and time (Adikurnia, 2018). In addition, the millennial generation is known as being tech-savvy, uses the Internet and social media as sources of information, and cares deeply about social values and status (Euromonitor, 2017). Based on research by the Harris Group in 2014, millennials are typically fond of uploading their travel photos to social media to gain social recognition (Saiidi, 2016). Millennials and generation-z consumers, who like to influence others, are also more likely to share their travel experiences online during the trip, thus actively spreading eWOM about the places they visit (Ek Styvén \& Foster, 2018).

According to MacCannell and Lippard (1999), a destination is considered able to improve the social status of its visitors if it has certain characteristics, one of which is worldwide recognition. Lombok has this attribute, as it is one of the world's favorite celebrity tourist destinations (Futureready, 2017). Furthermore, Lombok is globally renowned for its diverse natural and cultural beauty, which enhances its potential as a tourist attraction. Currently, however, the number of tourists visiting Lombok is still relatively small compared with Bali, which has a similar geographic location close to Lombok.

The Indonesia Tourism Balance Report in 2017, ranks the province of Nusa Tenggara Barat (NTB) in eighteenth place, according to the number of trips made by the population (according to its province), with West Java first and Bali eight (Deputi Bidang Pengembangan Kelembagaan Kepariwisataan Kementerian Pariwisata, 2017). The number of foreign tourists visiting Indonesia from January to June 2019 reached 7.83 million and obtained a 4.01\% rise compared with 2018 (7.53 million visits). When compared with visits in May 2019, the number of foreign tourists visiting tourist attractions in Indonesia through the air entrance in June increased by $16.57 \%$ or an annual increase of $1.81 \%$, with the largest increase occurring at the Lombok International Airport, West Nusa Tenggara, which amounted to $116.65 \%$ (Katadata, 2019b).

Therefore, the focus of tourism branding through online media, especially on digital social networking sites (SNS) that contain user-generated content (UGC) or sites/applications whose content comes from consumers (O'Connor, 2008) is important. Studies have found that word of mouth (WOM) is the main source of information in determining tourist destinations (88\%), compared with information presented by a company (77\%) (Nielsen, 2015). According to Gretzel and Fesenmaier (2009), tourists use the Internet (e.g., online customer support, emails, and online travel communities) during every stage of the tourism consumption process (Kim \& Jun, 2016). Furthermore, tourists typically carry their mobile phones to create content about their travels; further, $40 \%$ of people viewing the content are affected by the photos uploaded (Matador Network, 2013).

With regard to behavior relating to the distribution of tourism content, tourists are typically concerned about the context and imagery displayed in the uploaded content. Tourists tend to spread tourism content if it has an image congruency between the content itself and their self-concept. This is called self-congruity, i.e., adjusting their image or identity with the image of the product 
consumed or, in this case, the destination experienced (Sirgy, 1982). Such images are also used to trigger social conversations on social media. By uploading information related to their travel experience, those tourists feel more welcomed by their social group, as that kind of content will improve their positive impressions (Sweeney \& Soutar, 2001). Tourists tend to disseminate information online if a tour or destination offers an opportunity to influence or enhance their social value (Rihova, Buhalis, Moital \& Gouthro, 2015). This kind of behavior is commonly found among millennials, which is supported by research conducted by the Future Foundation in 2016, involving 8,000 tourists around the world. This research also shows that millennials upload more tourism content to social media than other generations (Saiidi, 2016). The self-congruity and perceived social value will also lead to other phenomena, e.g., experience satisfaction. Tourists will feel satisfied with a trip if it conforms with their self-image and lifestyle. They will be particularly satisfied if the experience gives them social recognition (Correia, Kozak, \& Reis, 2014).

Cortés's previous research (2017) has been replicated here because the research model fits with the topic. Cortés showed the influence of symbolic consumption in the form of self-owned congruity of tourists, perceived social value, and experience satisfaction toward the social network intensity of usage. Millennials as a unit analysis in this research are the heavy and intense users of social networks. For millennials as contemporary technology-savvy digital natives, social network applications (SNAs) such as Facebook, Twitter, and Pinterest serve as natural extensions to their social lives (Shirish, Boughzala, \& Srivastava, 2016). Moreover, this research aims to analyze if those three factors have impacts on the social network intensity of usage among millennials, while they visit Lombok as a tourist destination.

\section{LITERATURE REVIEW}

\subsection{Self-Congruity in Accordance with Perceived Social Value}

Sirgy (1982) states that self-congruity is the matching image of a product with the consumer's selfconcept. This is in line with the definition proposed by Correia et al., (2014), i.e., that self-congruity is the improvement of the consumer self-concept through consumption activities. In this study, tourists form a personal bond with their destination by adjusting the tourism image with their selfconcept. The context of self-congruity influences how travelers form the extent of their social values (Kim \& Jun, 2016). According to Monroe (1990), in Kim and Thapa (2017), a perception of value is the evaluation made by the consumer on the benefits obtained compared with the sacrifices given in the form of costs. In this context, we will only talk about the benefit in the social form, which relates to the image that tourists want to get from others (Kim \& Thapa, 2017).

With the self-congruity concept, tourists will experience a "relationship" with a particular tourist destination because it has a harmonious image with their self-concept. Self-congruity can then differentiate tourists based on their relationship or alignment with a destination (Ekinci, Sirakaya, \& Preciado, 2013). In addition, this differentiation will also influence which social group they belong. This is why the statement above noted self-congruity influences on how travelers form their social values. Hosany and Martin (2012) also support the theory that the perceived social value of a tour can be influenced by self-congruity. Accordingly, the researcher proposes the hypothesis: 


\section{H1: Experience self-congruity has a direct and positive influence on the perceived social value of Indonesian millennial tourists in Lombok.}

\subsection{Satisfaction}

Lovelock and Wirtz (2007) noted that satisfaction is a consumer's response to an assessment made through a consumer's interaction with a product or service. In the tourism sector, tourist satisfaction is the result of expectations that a tourist has before his/her trip compared with the experience received during the trip (Chen \& Chen, 2010). Perceived social value is one factor that has a great impact on the millennials' satisfaction as they appreciate social value and recognition (Saiidi, 2016). Tourists will be satisfied with a trip if it gives them social benefits (Sun, Wang, Lepp \& Robertson, 2014). This research uses several indicators to measure social value accrued by millennials during their trip. This includes greater acceptability among others, increased judgment, positive impressions gained from content uploaded, etc. (Cortés, 2017). In light of the importance of the social value obtained from customer satisfaction, we hypothesize:

\section{H2: Perceived social value has a direct and positive influence on experience satisfaction.}

\subsection{Digital Social Network}

A digital social network is a collection of Internet-based applications that built the ideology and technological foundations of Web 2.0. These technologies enable the creation and exchange of user-generated content (UGC) (Cabiddu, De Carlo, \& Piccoli, 2014). The consumer uses the social network to express his/her self-identity. Further, the consumer assumes that self-expression through social networks is the easiest way for self-expression (Stephen, 2016).

Tourists tend to show off their experiences through the content they publish on social networks to fulfill their needs for self-expression and self-presentation (Cortés 2017). In other words, by using social networks, tourists can strengthen their identities (Ahuvia, 2005). Consumers want others to be aware of what they saw and felt, i.e., their self-concept (Carú \& Cova, 2003), which is why Internet and digital social networks present an ideal opportunity for consumers to show the experiences that reinforce their identities. For this reason, we hypothesize:

\section{H3: Experience self-congruity has a direct and positive influence on the intensity of using a digital social network.}

Uploading travel content as a form of conspicuous consumption is necessarily done to show others that a tourist belongs to certain social groups. Ayeh, Au, and Law (2013) stated that a tourist will disseminate content if it contains the same value, interest, and will be liked by his/her social group. It is done in the hope that it can give one social recognition (Correia et al., 2014). Bock, Zmud, Kim, \& Lee (2005) also stated that the dissemination of content is motivated by the existence of certain advantages, one of which is social benefit (Cortés, 2017). Munar and Jacobsen (2016) supported the contention that social benefits are a significant motivation in informationdissemination behavior. Thus, it can be said that the perceived social value tourists derive through their travel experience can affect the intensity of using a digital social network (Rihova et al., 2015). Hence, we formed the following hypothesis: 
H4: Perceived social value has a direct and positive influence on the intensity of using a digital social network.

The level of consumer satisfaction is known as the main factor in spreading word of mouth (WOM) Wirtz \& Chew (2002). This means that the higher the level of customer satisfaction, the higher the possibility of consumers to spread the eWOM (Fu, Ju, \& Hsu, 2015). Satisfied consumers tend to share information with other consumers through such online community-based forums, e.g., Facebook and Twitter (Shin, Park, \& Ju, 2011). Gretzel and Yoo (2008) claimed there are two motivations for tourists to write a review, to help tourism service providers and to help other tourists make good decisions. This proposal is also supported by the theory of equity (Thurau, Gwinner, Walsh \& Gremler, 2004), which states that, if a customer feels that he/she has received good output from a company, then helping the company by recommending its services on the Internet is one way to equalize the equilibrium ratio. Therefore, we hypothesis:

H5. Experience satisfaction has a direct and positive influence on the intensity of using digital social networks.

Figure 1: Research Model

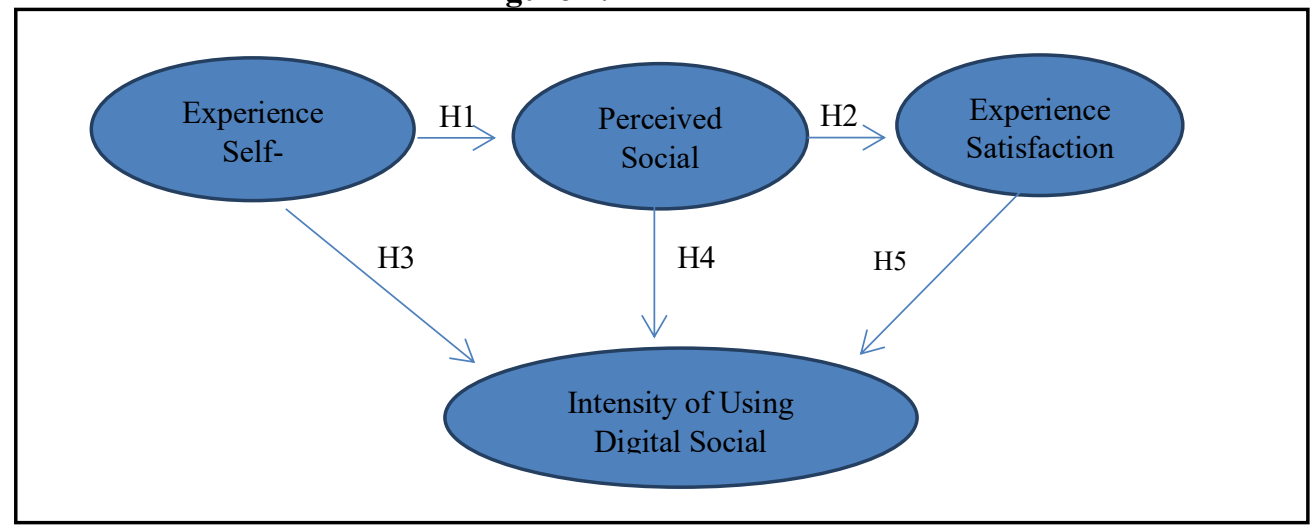

Source: Reprocessed by the author based on Cortés (2017)

\section{METHODOLOGY}

The hypothesis used in this study was tested through a survey among Indonesian Tourists (Wisnus) who have visited Lombok for leisure. The introduction reveals an increasing number of trips from Indonesian local tourists, which reached 303.4 million in 2018, which is a quite big number for a research population. The researcher used a self-administered questionnaire and a descriptive research design, as the purpose of this research is to test the existing hypotheses and the relationship between related variables.

Unit analysis of this study consists of 214 respondents throughout Indonesia, as the sample of this research. The respondents must meet eligibility that is based on several criteria; thus, this research uses judgmental sampling, i.e., a method of sampling in which researchers decide which part of the population meets the criteria required for participating in the study (Malhotra, 2010). The 
researcher spread the survey through an online community of Lombok Travellers on Facebook and other kinds of digital social networks.

Respondent criteria for this study include millennials aged 16-34 years who have traveled to Lombok Island in the past year, have used digital social networks, and have previously uploaded travel content in Lombok (e.g., photos, videos, status, geotags, or comments).

After the researcher obtained all related data gathered through the methods explained above, the data are cleared and entered into a data processor. The SPSS Data Processor is used to process the respondent's profile data. The Lisrel 8.51 data processor is used to test the data's reliability and validity. Lisrel is also used to evaluate the structural model and to estimate the set of coefficients for the causal relationship between variables and analyzed with the structural equation modelling (SEM) statistical technique.

\section{RESULTS AND DISCUSSION}

\subsection{Results}

This research analyzes Indonesian tourists who have visited Lombok. Those tourists range in age from 16 to 34 years (i.e., millennials). The table below summarizes the complete respondent profile that is used in this research.

Table 1: Respondent Profile

\begin{tabular}{|c|c|}
\hline Profile & Respondent's Answer \\
\hline Gender & Male $(43 \%) ;$ Female $(57 \%)$ \\
\hline Domicile & $\begin{array}{l}\text { DKI Jakarta, 29.91\%; Jawa Barat, 27.57\%; Banten, 10.28\%; DI } \\
\text { Yogyakarta, 8.41\%; Bali, 7.01\%; NTB, 4.21; Jawa Tengah, } \\
\text { 2.80\%; Sumatera Utara, 1.40\%; Kalimantan Selatan, } 1.40 \% \text {; } \\
\text { Sulawesi Selatan, } 0.47 \% \text {; Lampung, 0.47\%; Kepulauan Riau, } \\
0.47 \% \text {; Aceh, } 0.47 \%\end{array}$ \\
\hline Job & $\begin{array}{l}\text { College Student, } 71.50 \% \text {; Private Employee, } 17.29 \% \text {; State } \\
\text { Employee, } 2.80 \% \text {; Student, } 3.27 \% \text {; Entrepreneur, } 1.87 \% \text {; } \\
\text { Freelancer } 1.87 \% \text {; BUMN Employee, } 1.40 \%\end{array}$ \\
\hline Age & $\begin{array}{l}16-20 \text { years old, } 22.43 \% ; 21-25 \text { years old , } 71.03 \% ; 26-30 \\
\text { years old, } 5.14 \% ; 31-34 \text { years old, } 1.40 \%\end{array}$ \\
\hline Education & $\begin{array}{l}\text { Junior High School, 3.27\%; Senior High School, 76.17\%; } \\
\text { Bachelor, } 20.56 \%\end{array}$ \\
\hline Expenses per month (in average) & $\begin{array}{l}\text { Less than Rp } 1.000 .000(18.22 \%) \text {; Rp } 1.000 .001-\mathrm{Rp} 3.000 .000 \\
(58.88 \%) \text {; Rp } 3.000 .001-\mathrm{Rp} 6.000 .000(17.29 \%) ; \mathrm{Rp} \\
6.000 .001-\mathrm{Rp} 9.000 .000(4.21 \%) \text {; More than Rp } 9.000 .000 \\
(1.40 \%)\end{array}$ \\
\hline $\begin{array}{l}\text { Expenses per month for tourism (in } \\
\text { average) }\end{array}$ & $\begin{array}{l}\text { Less than Rp } 3.000 .000(31.31 \%) ; R p 3.000 .001-R p 5.000 .000 \\
(27.10 \%) \text {; Rp 5.000.001-Rp 7.000.000 (18.69\%); Rp } \\
7.000 .001-R p 10.000 .000(13.55 \%) \text {; More than Rp } 10.000 .000 \\
(9.35 \%)\end{array}$ \\
\hline Last time visited Lombok & $\begin{array}{l}\text { 1-3 month (29.91\%); 4-6 month (14.02\%); 7-9 month } \\
(18.22 \%) ; 10-12 \text { month }(37.85 \%)\end{array}$ \\
\hline
\end{tabular}




\begin{tabular}{|c|c|}
\hline Profile & Respondent's Answer \\
\hline Tourist destination in Lombok & $\begin{array}{l}\text { Gunung Rinjani (40 people); Kawasan Pantai Senggigi (125 } \\
\text { people); Narmada (35 people); Air Terjun Sendang Gile (30 } \\
\text { person); Gili (Trawangan, Air, Meno) (161 people); Pantai } \\
\text { Kuta (130 people); Desa Sade (88 people); Pantai Tanjung Aan } \\
\text { (92 people); Sembalun (50 people); Pantai Pink (54 people); } \\
\text { Air Terjun Tiu Kelep (4 people); Benang Kelambu (2 people); } \\
\text { Bukit Merese (20 people); Gili Kedis (4 people); Gili Nanggu } \\
\text { (7 people); Gili Sudak (5 people); Pantai Mawun (5 people); } \\
\text { Pantai Nipah (4 people); Pantai Pandanan (3 person); Pantai } \\
\text { Selong Belanak (5 people); Pantai Semeti (2 people); Pantai } \\
\text { Sekotong Indah (2 people); Air Terjun Benang Kelambu (1 } \\
\text { person); Air Terjun Mangkusaki (1 person); Bajo Pulo (1 } \\
\text { people); Batu Payung (1 person); Benang Stokel (1 person); } \\
\text { Bukit Pusuk (1 person); Malaka (1 person); Pantai Cemara (1 } \\
\text { person); Pantai Merese (1 person); Pantai Santigi (1 person); } \\
\text { Pantai Seger (1 person); Taman Sangakareang Mataram (1 } \\
\text { person); Tanjung Bongo (person); Gili Bidara (1 person); } \\
\text { Pantai Labuhan Haji (1 person); Pantai Pidana (1 person); Gili } \\
\text { Petelu (1 person); Ampenan (1 person); Tanjung Bloam (1 } \\
\text { person) }\end{array}$ \\
\hline $\begin{array}{l}\text { Types of digital social network that is } \\
\text { used }\end{array}$ & $\begin{array}{l}\text { Site and/or image sharing application (170 people); social } \\
\text { media ( } 125 \text { people); site and/or travel review application ( } 23 \\
\text { people); sSites and/or applications for various videos ( } 13 \\
\text { people); blog (13 people) }\end{array}$ \\
\hline $\begin{array}{l}\text { Time of used of digital social network } \\
\text { in a day }\end{array}$ & $\begin{array}{l}1-2 \text { hours }(27.10 \%) ; 3-4 \text { hours }(37.85 \%) ; 5-6 \text { hours } \\
(14.02 \%) ;>6 \text { hours }(21.03 \%)\end{array}$ \\
\hline
\end{tabular}

Source: Processed by the author on SPSS

Validity and reliability are shown in Table 2.

Table 2. Validity and Reliability Test

\begin{tabular}{ll}
\hline \hline Variables & Validity and Reliability Test Result \\
\hline \multirow{3}{*}{ Experience self-congruity } & KMO: 0,770 \\
& Factor Loading: CON1 (0.854); CON2 (0.862); CON3 (0.857); CON4 \\
& (0.781); CON5 (0.833) \\
& Cronbach's Alpha: 0.890 \\
\hline & KMO: 0.713 \\
& Factor Loading: VALS1 (0.872); VALS2 (0.795); VALS 3 (0.826); \\
Perceived social value & VALS 4 (0.916) \\
& Cronbach's Alpha: 0.872 \\
& KMO: 0,617 \\
& Factor Loading: SAT1 (0.891); SAT2 (0.783); SAT3 (0.770) \\
Experience satisfaction & Cronbach's Alpha: 0.902 \\
& KMO: 0,892 \\
& Factor Loading: DSN1 (0.914); DSN2 (0.901); DSN3 (0.913); DSN4 \\
The intensity of using digital & C.862); DSN5 (0.,847); DSN6 (0.879) \\
social network & Cronbach's Alpha: 0.945 \\
\hline \hline
\end{tabular}


After data validity and reliability are measured and proven to have good results, hypothesis testing is done via SEM using Lisrel 8.51 as the data processor. From a total of five hypotheses, two are rejected. We found a direct and positive influence among experience self-congruity on perceived social value, perceived social value on experience satisfaction, and perceived social value on the intensity of using digital social networks. But no direct and positive influence on experience selfcongruity on the intensity of using digital social networks and experience satisfaction on the intensity of using a digital social network. Table 3 and Figure 2 show the result of each hypothesis testing.

Table 3: Hypotheses Testing

\begin{tabular}{clcccc}
\hline \hline Hypotheses & Path & SLF & T-Value & Conclusion & Explanation \\
\hline H1 & $\begin{array}{l}\text { Experience self-congruity } \rightarrow \\
\text { Perceived Social Value }\end{array}$ & 0,48 & 6.15 & Significant & $\begin{array}{c}\text { Hypotheses } \\
\text { Accepted }\end{array}$ \\
\hline H2 & $\begin{array}{l}\text { Perceived Social Value } \rightarrow \\
\text { Experience Satisfaction }\end{array}$ & 0.30 & 3.84 & Significant & $\begin{array}{c}\text { Hypotheses } \\
\text { Accepted }\end{array}$ \\
\hline H3 & $\begin{array}{l}\text { Experience self-congruity } \\
\text { Intensity of Using Digital } \\
\text { Social Network }\end{array}$ & 0.05 & 0.67 & $\begin{array}{c}\text { Not } \\
\text { Significant }\end{array}$ & $\begin{array}{c}\text { Hypotheses } \\
\text { Rejected }\end{array}$ \\
\hline H4 & $\begin{array}{l}\text { Perceived Social Value } \rightarrow \\
\text { Intensity of Using Digital } \\
\text { Social Network }\end{array}$ & 0.50 & 5.71 & Significant & $\begin{array}{c}\text { Hypotheses } \\
\text { Accepted }\end{array}$ \\
\hline H5 & $\begin{array}{l}\text { Experience Satisfaction } \rightarrow \\
\text { Intensity of Using Digital } \\
\text { Social Network }\end{array}$ & 0.09 & 1.31 & $\begin{array}{c}\text { Not } \\
\text { Significant }\end{array}$ & $\begin{array}{c}\text { Hypotheses } \\
\text { Rejected }\end{array}$ \\
\hline \hline Source Procetw
\end{tabular}

Source: Processed by the author on SPSS

Figure 2: $T$-Value and Structural Model of SLF

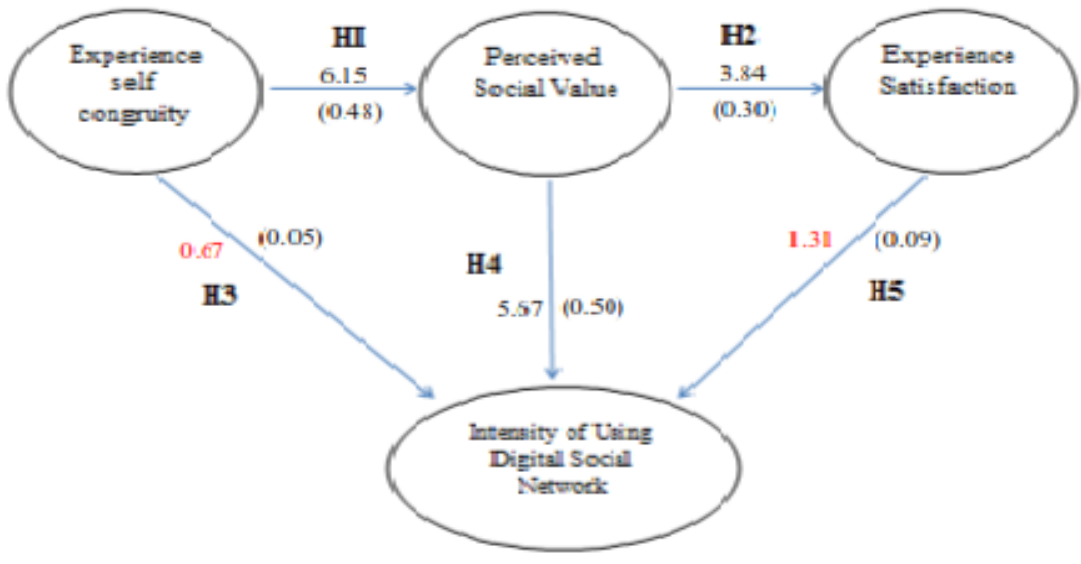

Source: Processed by the author on Lisrel 8.51 


\subsection{Discussion}

Here, we discuss theoretical implications from the analysis of statistical results and managerial implications that consist of recommendations for the West Nusa Tenggara government.

\subsubsection{Theoretical Implications}

The hypothesis testing shows a direct and positive relationship between experience self-congruity and perceived social value; further, it indicates that the more congruent one's self-concept with the destination image, the more social value he/she will obtain (Kim \& Jun, 2016). It is happening as in the self-congruity concept, i.e., tourists will have a "relationship" with a particular tourist destination because of their harmonious image. Self-congruity can then differentiate tourists based on their relationship or alignment with a destination (Slater, 1997, in Ekinci, 2013). In addition, this differentiation will also influence which social group they belong to (Slater, 1997, in Ekinci, 2013), which means the statement "self-congruity influences how travelers form their social values" can be accepted. Hosany and Martin (2012) also support the theory that self-congruity can influence the perceived tour's social value. This proposition is also supported by Sparks, Bradley, and Jennings (2011) and Hosany and Martin (2012).

Perceived social value is important to millennials, whose behavior is generally motivated by a desire to gain social recognition from others. This statement is supported by research conducted by the Future Foundation in 2016, which compared three generations: generation x, millennial, and baby boomers. This research found that millennials are more concerned about the social benefit they would gain during certain activity compared with that of other generations. The social benefits gained by millennials per this study are social acceptance, increased judgment, and the emergence of positive impressions from others (Cortés, 2017; Correira, Kozak, \& Reis, 2014). According to Kim and Thapa (2017), the emotional and social values have a greater influence on the level of customer satisfaction than on functional value. Consuming tourism products could enhance one's social image as it helps to communicate his/her symbolic meanings (Kim, Gupta, \& Koh, 2011, in Kim \& Thapa, 2017). By showing the society that the customers are sharing the same values and lifestyle means that they can meet the social norms and standards required to be part of that social group, which leads to satisfaction (Chiu et al., 2014; Lee \& Moscardo, 2005).

With the possibility of obtaining this kind of social benefit, millennials are typically motivated to accrue social benefits by carrying out various activities, one of which is disseminating content about their travels. Before disseminating their travel content, travelers will evaluate the costs and benefits they will gain from the action (Blau, 1964; Emerson, 1962; Homans, 1958, in Osatuyi, 2013). Munar and Jacobsen (2016) suggest that social benefits are the most significant motivation for disseminating information, especially among millennials.

Millennials is a generation that rates social values highly; hence, they tend to be motivated to do things to accrue such benefits. This is driven by a behavioral impulse, which is generally found among millennials, called "fear of missing out" (FoMO). FoMO is a fear that arises from feelings and assumptions that other people have a better life (Bailey, Bonyfield, \& Arias (2018). According to the literature, FoMO is the most significant factor that explains the intensity of social media usage. Przybylski, Murayama, DeHaan, \& Gladwell (2013) argue that those who suffer from FoMO tend to be more interested in using social media because it will facilitate their social 
connections and help them to benefit socially. According to McCracken (1988) and Muñiz and O'Guinn (2001), in Correia et al., (2014), only through visible practices of conspicuous consumption, such as uploading travel content to social media, could they gain the desired level of recognition, where the product or content they upload applies as a signaling status.

Therefore, things such as the suitability of the self-concept with the destination image or the level of satisfaction gained during the millennials' travels will not necessarily encourage them to spread their travel content. They will not distribute content if there is no social benefit. In other words, the main goal of millennials in the dissemination of tourist content is to acquire social benefits-and not because of the suitability of the image nor to help others gain a similar level of satisfaction. Based on Ghaisani, Handayani, and Munajat (2017), helping others as a motivation to disseminate certain information has proven to be less significant among Indonesian millennials compared with the motivation to gain social benefits in order to establish relationships with certain social groups.

Moreover, the compatibility between self-concept and destination image tends to encourage tourists not to use social media. It is happening because such compatibility will lead to increased enjoyment, and those who enjoy a trip are often too busy to use social media. This is because taking photos requires attention, which can be time-consuming. Photography allows tourists to enjoy the tourist experience in the future but makes them lose the actual moment on a tour (Hershberger, 2013). Those who do not take photos tend to enjoy the travel more and will remember their experiences more clearly than those who do take photos (Henkel, 2014 in O'Malley, 2017).

Tourists who enjoy travel tours tend not to use social media on their trips because it will interfere with their pleasure. A parable uploaded on huffingtonpost.com illustrates the point. When tourists are busy capturing good content to upload to Instagram, Facebook, Twitter, Snapchat, or even YouTube, they are typically distracted from enjoying the tour, so they actually don't experience the essence of their trip. One reason is that a tourist will tend to continually revisit a social media account to see how many likes or comments he/she received. This may prompt the tourist to wonder why the content has not received an anticipated response (Langford, 2016).

\subsubsection{Managerial Implications}

Based on the results of this study, the researcher offers managerial implications that can be used by the government of West Nusa Tenggara to develop the tourism sector and also attract millennials as a targeted market for tourist destinations in West Nusa Tenggara. First, the trend of conspicuous consumption among tourists by uploading their travel content to social media could be used. This is done so lesser-known tourist destinations in Lombok, such as Gili Kedis, Gili

Nanggu, Tiu Kelep Waterfall, Bajo Pulo, Batu Payung, and so forth, could increase their popularity. This could also be done by inviting celebrities to visit many of the less-visited destinations in Lombok. Influencers can be used to increase awareness among tourists about Lombok's remote destinations. Furthermore, both government and private parties could build the unique photo spots to encourage tourists to take pictures and upload them to social media. This is done to increase awareness of Lombok tourism. Photo spots should be supported by a unique design, furniture, and the ambiance of restaurants, hotels, and attractions in Lombok, in the hope that these will motivate tourists to upload their travel content. 
Second, the government can also collaborate with event organizers and sponsors to create a cultural festival in Lombok, to attract domestic and foreign tourists, and make this festival go viral through a "Go Online and Tell Your Story about Lombok" campaign theme in social media. This would ensure widespread coverage through social media as the second most widely used communication channel by Indonesians after using a chat application. Such a strategy would increase public awareness of Lombok tourism.

\section{CONCLUSION}

\subsection{Key Findings}

This study has shown that the self-image of tourists is congruent with the image of the attractions Lombok has to offer as tourist destinations. The compatibility between tourists' self-image and destination image (in this case, Lombok) forms a differentiation between tourists and the influence of their perceived social value. With this congruence, tourists can then create positive impressions of themselves. But this self-congruity experience does not have a positive and significant influence on the desire for tourists to upload content to social networks. This proves that the compatibility of self-image with the destination image does not guarantee that tourists will upload content about the tour.

Then, tourists who visited Lombok have increased their perceived social value. That is, by traveling to Lombok, the tourists' self-image will increase, which will help them to get into certain social groups and achieve social recognition. To achieve social recognition, tourists usually engage in conspicuous consumption via uploading tour content to digital social networks. Therefore, it can be seen that the tourist's perceived social value in Lombok influences their intensity to upload their trip content to social networking sites.

The social benefits obtained by tourists will also increase their level of satisfaction with their travel to Lombok. In other words, the greater the social benefits obtained by tourists, the greater their perceived satisfaction. However, this does not become a driving force for tourists to upload their travel content to digital social networks, i.e., satisfaction is not a reason for tourists to upload tourrelated content to the Internet.

\subsection{Limitations}

A limitation to this study is that it includes only local millennials and domestic tourists. This sample could be extended to include tourists from abroad across a diverse range of ages. Further research could also compare the behavior of domestic tourists with that of foreign tourists who visit Lombok's tourism destinations and compare various segments of the generation. Future research will also be able to use more specific digital social networking sites by choosing Facebook or Instagram, for example, to gain a deeper understanding.

Future studies could also extend their scope to other areas because tourist behaviors may be different if the object of research is replaced by other tourist destinations. Future research could also add an "intention to repost" variable to establish tourists' desires to re-upload details of their trip content or add a "destination images" variable, so the researcher could assess its influence on 
the self-congruity variable and perceived social value, in order to obtain more comprehensive results.

\section{ACKNOWLEDGMENT}

This research was supported by Direktorat Riset dan Pengabdian Kepada Masyarakat (DPRM UI). Thank you for the funding and your generosity. We also thank our colleagues from the University of Indonesia and judges of International Conference of Business and Management Research (ICBMR) 2018 who provided insight and expertise that greatly assisted the research. We thank Mrs. Ira Iriyanti and Mr. Rachmadi for comments that greatly improved the manuscript.

\section{REFERENCES}

Ahuvia, A. C. (2005). Beyond the extended self: Loved objects and consumers' identity narratives. Journal of Consumer Research, 32(1), 171-184.

Ayeh, J. K., Au, N., \& Law, R. (2013). Predicting the intention to use consumer-generated media for travel planning. Tourism Management, 35, 132-143.

Bailey, A., Bonyfield, C., \& Arias, A. (2018). Social media use by young latin american consumers: An exploration. Journal of Retailing and Consumer Services, 43, 10-19.

Bock, G. W., Zmud, R. W., Kim, Y. G., \& Lee, J. N. (2005). Behavioral intention formulation in knowledge sharing: Examining the roles of extrinsic motivators, social-psychological forces, and organizational climate. MIS Quarterly, 29(1),87-111.

Cabiddu, F., De Carlo, M., \& Piccoli, G. (2014). Social media affordances: Enabling customer engagement. Annals of Tourism Research, 48, 175-192.

Carù, A., \& Cova, B. (2003). Revisiting consumption experience: A more humble but complete view of the concept. Marketing theory, 3(2), 267-286.

Chen, C. F., \& Chen, F. S. (2010). Experience quality, perceived value, satisfaction and behavioral intentions for heritage tourists. Tourism Management, 31(1), 29-35.

CNBC. (2016). Millennials are prioritizing "experiences" over stuff. Retrieved from https://www.cnbc.com/2016/05/05/millennials-are-prioritizing-experiences-overstuff.html

Correia, A., Kozak, M., \& Reis, H. (2014). Luxury tourists: Celebrities' perspectives', tourists' perceptions and assessments. Advances in Culture, Tourism and Hospitality Research, 8, 43-51.

Cortés, G. (2017). The influence of symbolic consumption on experience value and the use of virtual social networks. Spanish Journal of Marketing, 21(1), 39-51.

Deputi Bidang Pengembangan Kelembagaan Kepariwisataan Kementerian Pariwisata. (2017). Neraca Satelit Pariwisata Nasional. Retrieved from http:/www.kemenpar.go.id/userfiles/Buku\%20I\%20Nesparnas\%202017.pdf

Ek Styvén, M., \& Foster, T. (2018). Who am I if you can't see me? The "self” of young travelers as driver of eWOM in social media. Journal of Tourism Futures, 4(1), 80-92.

Ekinci, Y., Sirakaya, E., \& Preciado, S. (2013). Symbolic consumption of tourism destination brands. Journal of Business Research, 66(6), 711-718. doi:10.1016/j.jbusres.2011.09.008

Euromonitor. (2017). Travel in Indonesia. Retrieved from http://www.euromonitor.com/travel-inindonesia/report 
Fu, J. R., Ju, P. H., \& Hsu, C. W. (2015). Understanding why consumers engage in electronic wordof-mouth communication: Perspectives from theory of planned behavior and justice theory. Electronic Commerce Research and Applications, 14(6), 616630. doi:10.1016/j.elerap.2015.09.0 03.

Futureready. (2017). 9 Destinasi Top Di Indonesia Favorit Selebriti Dunia. Retrieved from https://www.futuready.com/artikel/lifestyle-leisure/9-destinasi-top-di-indonesia-favoritselebriti-dunia/

Ghaisani, A., Handayani, P., \& Munajat, Q. (2017). Users' motivation in sharing information on social media. Procedia Computer Science, 124, 530-535.

Gretzel, U., \& Fesenmaier, D. R. (2009). Trust in travel-related consumer-generated media. In Höpken, W., Gretzel, U., \& Law, R. (Eds). Information and Communication Technologies in Tourism (pp. 49-59). New York, NY: Springer.

Gretzel, U., \& Yoo, K. H. (2008). Use and impact of online travel reviews. In P. O'Connor, W. Höpken, \& U. Gretzel (Eds.) Information and communication technologies in tourism (pp. 35-46). Vienna: Springer.

Hosany, S., \& Martin, D. (2012). Self-image congruence in consumer behavior. Journal of Business Research, 65, 685-691.

Katadata. (2019a). Jumlah Kunjungan Wisatawan Mancanegara Pada Juni 2019 Naik 15.48\%. Retrieved from https://katadata.co.id/berita/2019/08/01/jumlah-kunjungan-wisatawanmancanegara-pada-juni-2019-naik-1548.

Katadata. (2019b). Jumlah Perjalanan Wisatawan Wusantara 2018 Tumbuh 12\%. Retrieved from https:/databoks.katadata.co.id/datapublish/2019/07/03/jumlah-perjalanan-wisatawannusantara-2018-tumbuh-12

Kementrian Pariwisata Republik Indonesia. (2016). Pembangunan Destinasi Pariwisata Prioritas 2016-2019. Retrieved from http://perpustakaan.bappenas.go.id/lontar/file?file=digital /166694-[Konten]-Konten\%20D1812.pdf

Kim, M., \& Thapa, B. (2017). Perceived value and flow experience: Application in a nature-based tourism context. Journal of Destination Marketing \& Management, 8, 373-384.

Kim, S., \& Jun, J. (2016). The impact of event advertising on attitudes and visit intentions. Journal of Hospitality and Tourism Management, 29, 1-8.

Kompas. (2018). 3 Destinasi Domestik Favorit Millenial Tahun 2018. Retrieved from https://ravel.kompas.com/read/2018/04/13/213400127/3-destinasi-domestik-favoritmilenial-tahun-2018?utm_source=Twitter\&utm_medium=Social\&utm_campaign=Dlvrit

Langford, A. (2016 April, 10). Is social media ruining your vacation?. Huffington Post. Retrieved from https:/www.huffingtonpost.com/entry/is-social-media-ruining-yourvacation_us_ $57 \mathrm{f} 41218 \mathrm{e} 4 \mathrm{~b} 02 \mathrm{~d} 64 \mathrm{cba} 52 \mathrm{db} 4$

Lee, W. H., \& Moscardo, G. (2005). Understanding the impact of ecotourism resort experiencing on tourists' environmental attitudes and behavioral intentions. Journal of Sustainable Tourism, 13(6), 546-565.

Lovelock, C., \& Wirtz, J. (2007). Service marketing: People, technology, strategy (6th ed). United States of America: Pearson Prentice-Hall.

MacCannell, D., \& Lippard, L. R. (1999). The tourist: A new theory of leisure class. California \& London: University of California Press.

Malhotra, N. (2010). Marketing research: An applied orientation $\left(6^{\text {th }}\right.$ ed). New Jersey: Pearson Education, Inc.

Matador Network. (2013). Why I don't take pictures when $i$ travel. Retrieved from https://matadornetwork.com/bnt/why-i-dont-take-pictures-when-i-travel/ 
Munar, A., \& Jacobsen J. (2016). Motivations for sharing tourism experiences through social media. Tourism Management, 43, 46-54.

Nielsen (2015). Word-of-mouth recommendations remain the most credible. Retrieved from http://www.nielsen.com/id/en/press-room/2015/WORD-OF-MOUTHRECOMMENDATIONS-REMAIN-THE-MOST-CREDIBLE.html

O'Connor, P. (2008). User-generated content and travel: A case study on tripadvisor.com. Information and Communication Technologies in Tourism, 47-58.

O'Malley, K. (2017, August 8). Taking a photo will affect how you remember the moment, claims new study. ELLE. Retrieved from https://www.elle.com/uk/life-andculture/culture/news/a37613/photos-affects-memory-new-study/

Osatuyi, B. (2013). Information sharing on social media sites. Computers in Human Behavior 29, $2622-2631$.

Przybylski, A. K., Murayama, K., DeHaan, C. R., \& Gladwell, V. (2013). Motivational, emotional, and behavioral correlates of fear of missing out. Computers in Human Behavior, 29(4), 1841-1848.

Rihova, I., Buhalis, D., Moital, M., \& Gouthro, M. B. (2015). Conceptualising customer-tocustomer value co-creation in tourism. International Journal of Tourism Research, 17, 356363.

Shin, J., Park, M., \& Ju, Y. (2011, July 12-16). The effect of the online social network structure characteristics on network involvement and consumer purchasing intention: Focus on korean social promotion sites. Paper presented at the 11th International DSI and the 16th APDSI Joint Meeting, Taipei, Taiwan.

Shirish, A., Boughzala, I., \& Srivastava, S. (2016). Adaptive use of social networking applications in contemporary organizations: Examining the motivations of Gen Y cohorts. International Journal of Information Management, 36(6), 1111-1123.

Sirgy, M. J. (1982). Self-concept in consumer behavior: A critical review. Journal of Consumer Research, 9, 287-300.

Sparks, B., Bradley, G., \& Jennings, G. (2011). Consumer value and self-image congruency at different stages of timeshare ownership. Tourism Management, 32, 1176-1185.

Stephen, A. (2016). The role of digital and social media marketing inconsumerbehavior. Current Opinion in Psychology, 10, 17-21.

Sun, X., Wang, P., Lepp, A., \& Robertson, L. (2014). Symbolic consumption and brand choice: China's youth hostels for the international travel market. Journal of China Tourism Research, 10(1), 51-68. doi: 10.1080/19388160.2013.870950

Sweeney, J. C., \& Soutar, G. N. (2001). Consumer perceived value: The development of a multiple item scale. Journal of Retailing, 77(2), 203-220.

Thurau, T., Gwinner, K., Walsh, G., \& Gremler, D. Electronic. (2004). Word-of-mouth via consumer-opinion platforms: What motivates consumers to articulate themselves on the internet? Journal of Interactive Marketing. DOI: 10.1002/dir.10073Johar

Tripbarometer. (2016). Traveler Trends and Motivations: Global Findings. Retrieved from https://d2bxpc4ajzxry0.cloudfront.net/TripAdvisorInsights/sites/default/files/downloads/2 750/tripbarometer_2016_full_report_-_04_oct_2016_-_st12.compressed.pdf

Wirtz, J., \& Chew, P. (2002). The effects of incentives, deal proneness, satisfaction and tie strength on word-of-mouth behavior. International Journal of Service Industry Management, 13(2), $141-162$. 